\title{
Testing and Correlation of 8mm Pitch Honeycomb \& Plate Type Module Performance in a 20 Litres SCR Test Facility
}

\author{
D. Eswaraiah, G. Karthik, U. Harish Kumar
}

\begin{abstract}
The main aim of this experiment is to reduce the concentration of $\mathrm{NO}_{x}$ in the exhaust gas below 100ppm with the most effective technique named selective catalytic reduction (SCR) with ammonia over to evaluate the performance of honeycomb and plate type catalyst in $\mathrm{NO}_{x}$ reduction by varying the performance parameters such as flue gas temperature, space velocity, $\mathrm{NH}_{3} / \mathrm{NO}$ molar ratio, etc., and to find the optimum values of the above parameters under which we get the maximum efficiency of $\mathrm{NO}_{x}$ conversion at which air is not polluted and we have the sustained and eco-friendly environment. The effect of various performance parameters on the SCR process is also evaluated and the optimum values of performance parameters are also found to get the maximum efficiency of $\mathrm{NO}_{x}$ conversion. SCR performance is substantially under the effects of reactant (ammonia) concentration and operating temperature, so that the concentration of untreated ammonia emitted from reactor discharge (ammonia slip) increases significantly at $\mathrm{NH}_{3} / \mathrm{NO}$ ratios of more than 1.14 and operating temperatures less than $360{ }^{\circ} \mathrm{C}$ and $300{ }^{\circ} \mathrm{C}$, respectively, in the catalytic filter medium and honeycomb reactor. low level of ammonia slip can be achieved at the $\mathrm{NH}_{3} / \mathrm{NO}$ ratio of 1 and temperature range of $300-350{ }^{\circ} \mathrm{C}$ in both reactors. The temperature of SCR is varied between $300^{\circ} \mathrm{C}$ to $350^{\circ} \mathrm{C}$, with a fixed space velocity of exhaust gas and a fixed value of $\mathrm{NH} 3 / \mathrm{NO}$ ratio of 1 .
\end{abstract}

Keywords: SCR, honeycomb, plate, catalyst, $\mathrm{NO}_{x}$ reduction, space velocity, pressure drop, ammonia slip.

\section{INTRODUCTION}

The concentration of poisonous gases and toxic pollutants in the atmospheric air is drastically increasing due to the combustion of fossil fuels and atmospheric cycles. If the same situation is continued for few more decades then the human survival on the earth shall become a big challenge and the human species are going to extinct on earth. In recent years the problem of air pollution caused by the toxic pollutants such as $\mathrm{NO}_{\mathrm{x}}, \mathrm{SO}_{\mathrm{x}}$ and particulate matter has become very severe that the india has decided take stringent action against it. In view of the toxic pollutants, The ministry

Revised Manuscript Received on February 05, 2020.

* Correspondence Author

D. Eswaraiah *, Mechanical Engineering Department, GRIET, Hyderabad, India. Email: d.eswaraiah@gmail.com

G.Karthik, Mechanical Engineering Department, GRIET, Hyderabad, India. Email: karthikchowdary351@gmail.com.

U. Harish Kumar: Mechanical Engineering Department, GRIET, Hyderabad, India. Email: harishrockz6@gmail.com

(C) The Authors. Published by Blue Eyes Intelligence Engineering and Sciences Publication (BEIESP). This is an open access article under the CC BY-NC-ND license (http://creativecommons.org/licenses/by-nc-nd/4.0/) of environment and forest (MOEF), GOI issued notification for implementation of emission norms for particulate matter (PM), sulphur di-oxide $\left(\mathrm{SO}_{2}\right)$, oxides of nitrogen $\left(\mathrm{NO}_{\mathrm{x}}\right)$ and mercury (Hg). The final emission limits under title IV, promulgated in february 1998, are shown in table below 1 .

Table 1. TPPs regulatory norms installed from 1st Jan,

2017

\begin{tabular}{|c|c|c|c|}
\hline S.No. & Industry & Parameter & Standards \\
\hline \multirow{4}{*}{1.} & \multirow{4}{*}{$\begin{array}{l}\text { Thermal } \\
\text { Power Plant }\end{array}$} & $\begin{array}{l}\text { Particulate } \\
\text { Matter }\end{array}$ & - $\quad 30 \mathrm{mg} / \mathrm{Nm}^{3}$ \\
\hline & & $\left(\mathrm{SO}_{2}\right)$ & - $\quad 100 \mathrm{mg} / \mathrm{Nm}^{3}$ \\
\hline & & $\left(\mathrm{NO}_{\mathrm{x}}\right)$ & $100 \mathrm{mg} / \mathrm{Nm}^{3}$ \\
\hline & & (Hg) & $0.03 \mathrm{mg} / \mathrm{Nm}^{3}$ \\
\hline
\end{tabular}

Oxides of nitrogen $\left(\mathrm{NO}_{\mathrm{x}}\right)$ are a group of air pollutants, including nitrogen oxide, nitrogen dioxide and nitrous oxide, considered as very dangerous, since they contribute to the greenhouse effect and participate in photochemical reactions that lead to acid rain, troposphere ozone and respiratory problems in humans. So, the reduction of $\mathrm{NO}_{\mathrm{x}}$ from stationary and mobile sources has become an important concern of industrialized countries, due to an increased attention to environmental pollution and to the demand for sustainable energy development.

Hence, the elimination of gaseous pollutants and particles from high temperature gases is often required in waste incineration and thermal power plants. There are two sources of $\mathrm{NO}_{\mathrm{x}}$. One of them occurs in nature (nitrogen fixation by lightning, volcanic activity, oxidation of ammonia in the troposphere, inflow of NO from the stratosphere). The other is the combustion of fossil fuels (especially in vehicles) that is the main cause of emissions. So the emission of $\mathrm{NO}_{\mathrm{x}}$ caused by the combustion of fossil fuel has to be reduced by scientific methods. The control of $\mathrm{NO}_{\mathrm{x}}$ emissions from stationary sources includes techniques of modification of the combustion stage (primary measures) and treatment of the effluent gases (secondary measures).

SCR method, which was established in the 1970s, has been used mainly for stationary sources and still is the major strategy for the reduction of $\mathrm{NO}$, industrially, due to its high efficiency and the ability of ammonia to react selectively with $\mathrm{NO}_{\mathrm{x}}$ to form nitrogen $\left(\mathrm{N}_{2}\right)$ and water $\left(\mathrm{H}_{2} \mathrm{O}\right)$, together with the resistance to poisoning and aging of the applied catalysts. 


\section{OVERVIEW OF SCR}

\section{A. Selective Catalytic Reduction (Scr)}

SCR is a process, where ammonia $\left(\mathrm{NH}_{3}\right)$ is injected into flue gas stream, allowing the ammonia $\left(\mathrm{NH}_{3}\right)$ to selectively react with oxides of nitrogen ( $\mathrm{NOx}$ ) mainly nitrous oxide (NO) \& nitrogen di-oxide $\left(\mathrm{NO}_{2}\right)$ and decompose them into water $\left(\mathrm{H}_{2} \mathrm{O}\right)$ and nitrogen $\left(\mathrm{N}_{2}\right)$ in presence of catalyst. Aammonia is injected into exhaust gases containing NOx. The gases mix thoroughly in a turbulent zone, and then pass through the catalyst where the NOx is reduced. The technique is known as "selective" because the reducing agent will preferentially react with $\mathrm{NOx}$ instead of $\mathrm{O}_{2}$ at the proper temperature. The term "reduction" is used because the nitrogen is chemically reduced from an oxidized form to molecular nitrogen.

\section{SCR Advantages}

- Low consumption of ammonia

- Emission levels below $100 \mathrm{mg} / \mathrm{Nm}^{3}$ can easily be achieved

- $\quad$ Side effect - dioxin reduction

\section{SCR Disadvantages}

- High cost of investment dependent on NOx reduction level,

- High operational cost,

- Risk of ammonia slip,

- Catalyst life time,

- $\quad$ Storage of used catalysts.

\section{B. Chemical Reactions}

The $\mathrm{NH}_{3}$-SCR reduction of NO over a V2O5/TiO2 catalyst can be described by a reaction network that involves two parallel reactions. The desired reaction is the conversion of $\mathrm{NO}$ to $\mathrm{N}_{2}$ according to Equation (1), while $\mathrm{NH}_{3}$ oxidation with $\mathrm{O}_{2}$, based on Equation (2) is an undesired reaction which leads to lower NO conversion and becomes more significant at higher temperatures. The reduction of NOx is considered to be faster compared to NO, so that NOx typically consists of up to $95 \% \mathrm{NO}$, especially at high temperatures.

$$
\begin{aligned}
& 4 \mathrm{NO}+4 \mathrm{NH}_{3}+\mathrm{O}_{2} \square 4 \mathrm{~N}_{2}+6 \mathrm{H}_{2} \mathrm{O} \text {--- (1) } \\
& 4 \mathrm{NH}_{3}+3 \mathrm{O}_{2} \square 2 \mathrm{~N}_{2}+6 \mathrm{H}_{2} \mathrm{O} \text { - }
\end{aligned}
$$

\section{EXPERIMENTAL SYSTEM DESCRIPTION}

The experiments were conducted in 20 litres capacity selective catalytic reduction (SCR) test facility with $8 \mathrm{~mm}$ pitch honeycomb and plate type catalyst. The $8 \mathrm{~mm}$ pitch honeycomb and plate installed in 20 litres capacity selective catalytic reduction (SCR) test facility to evaluate the De- $\mathrm{NO}_{\mathrm{x}}$ efficiency at various space velocities and various SCR inlet temperatures. The existing 200mm APFBG pilot plant was operated in a combustion mode and generated flue gas for testing of 20 litres capacity honeycomb and plate catalyst for $\mathrm{NO}_{\mathrm{x}}$ reduction. The Process and Instrumentation Diagram (P\&ID) and Pictorial View of SCR test facility for De- $\mathrm{NO}_{\mathrm{x}}$ process is shown in Figure 1(a) \& 1(b) respectively. The performance of honeycomb and Plate catalyst was tested with dust concentration of $30-52$ grams $/ \mathrm{Nm}^{3}$ in flue gas. The experimental setup comprises of the following systems/sub-systems and are explained subsequently,

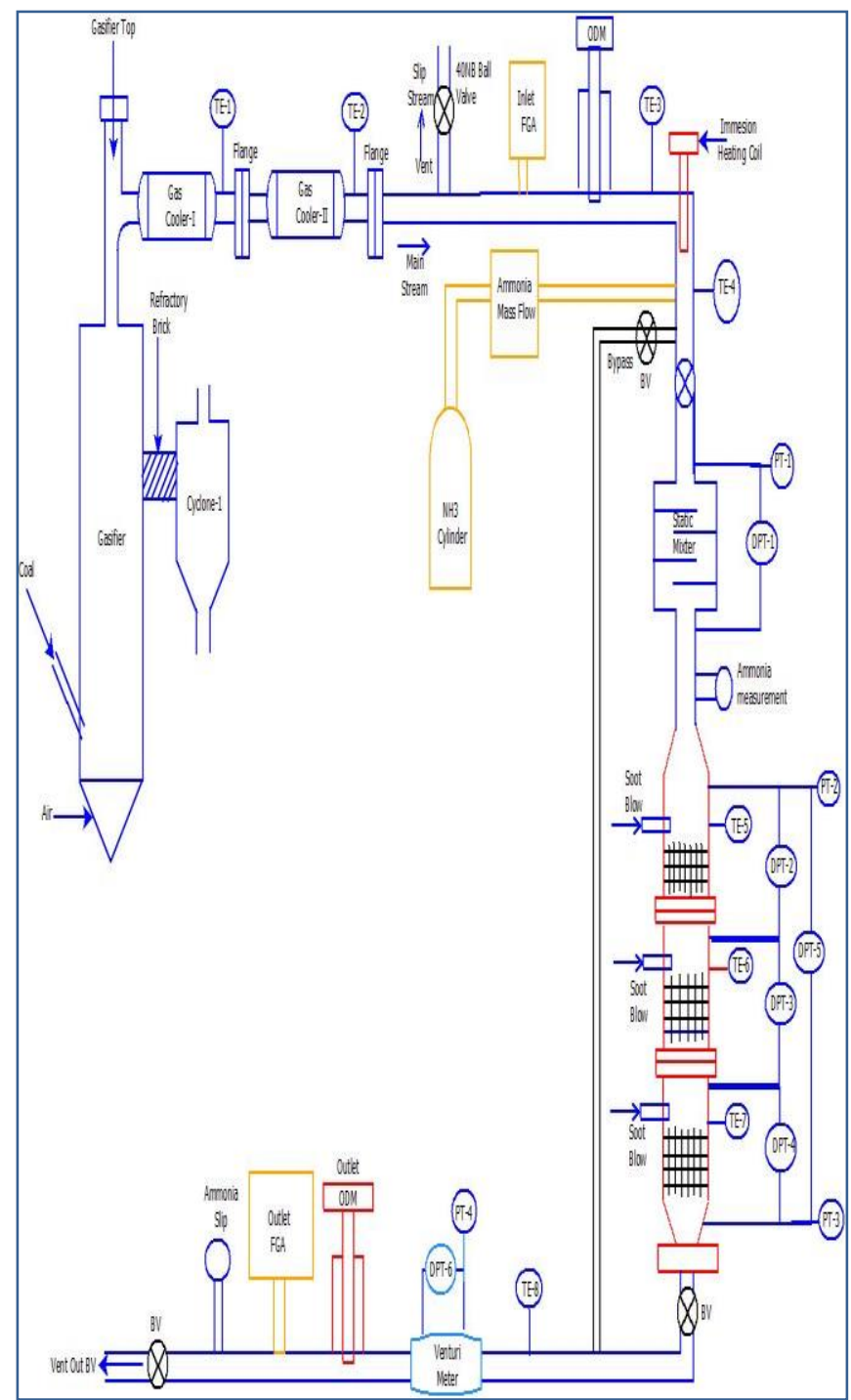

Figure 1. Process \& Instrumentation Diagram of 20 litres capacity SCR test facility

$\begin{array}{cl}\text { s.no } & \text { Sub System } \\ 1 & \text { APFBG test facility } \\ 2 & \text { Flue Gas Cooler-I \& II } \\ 3 & \text { On-line Dust Monitoring system } \\ 4 & \text { NOx Measurement System } \\ 5 & \text { Ammonia Injection system } \\ 6 & \text { Static Mixture } \\ 7 & \text { SCR Reactor Housing } \\ 8 & \text { SCR Catalyst } \\ 9 & \text { Venturi Flow Meter } \\ 10 & \text { Ammonia Slip measurement System }\end{array}$

\section{APFBG TEST FACILITY}

Advanced Pressurized Fluidized Bed Gasification (APFBG) pilot plant was to use generated flue gases for testing the SCR reactor.

\section{FLUE GAS COOLER-I \& II}

The purpose of the flue gas coolers are used to cool the flue gas from 400 Deg. C to 300 Deg. C. Since the testing of 
catalyst was proposed between 300-350 Deg.C, the flue gas coolers cool and maintain the required temperature at inlet of SCR reactor. Thermocouples are also installed to measure the flue gas temperature at inlet, outlet and between the cooler.

\section{DUST MEASUREMENT SYSTEM}

The main objective of the present project is to evaluate the performance of SCR honeycomb and plate catalyst with higher dust concentration of about 30 to $52 \mathrm{grams} / \mathrm{Nm}^{3}$ in flue gas. To achieve the above objective, the generated flue gas from APFBG test facility is admitted in to dust measurement system and measured the dust concentration in flue gas. The following are the specifications of the on-line dust monitoring system

\section{NO $_{x}$ MEASUREMENT SYSTEM}

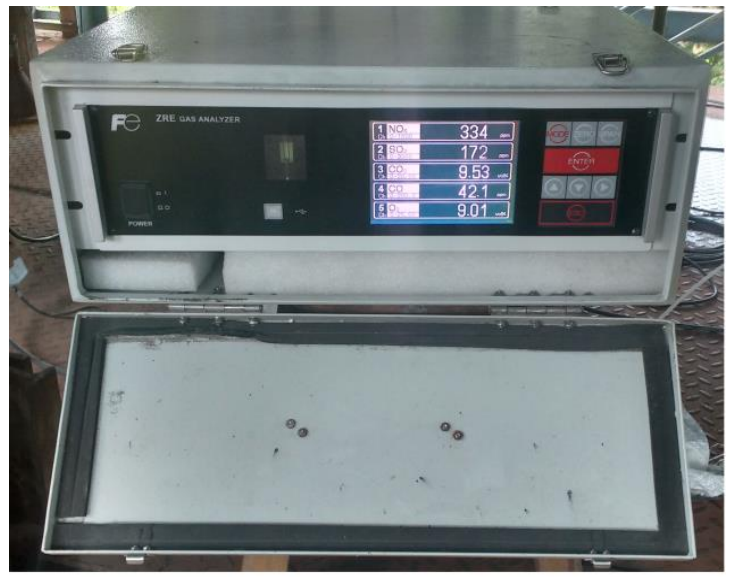

Figure 2(a) Flue Gas analyser.

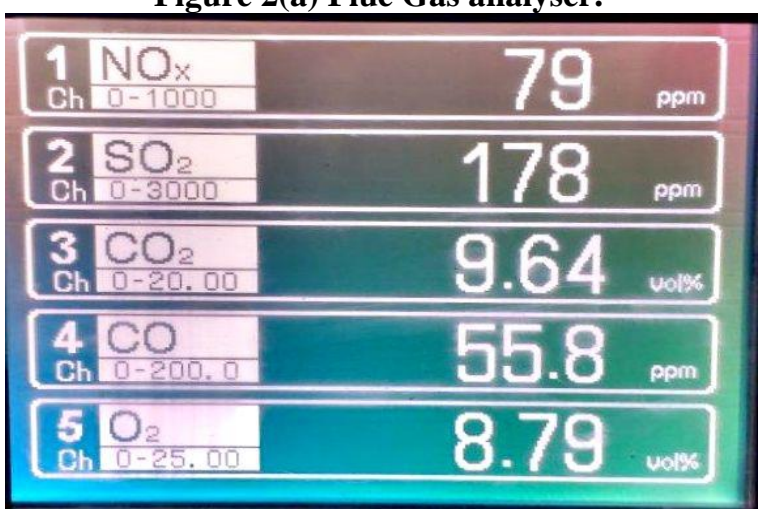

Figure 2(b). Flue Gas Composition.

\section{AMMONIA INJECTION SYSTEM}

Anhydrous ammonia is used as reducing agent for De-NO system in SCR technology. In this system, A 0.5mm nozzle is used for injecting the ammonia in to flue gas pipe line with the help of ammonia mass flow controller. The specifications of the ammonia mass flow controller are shown in below Table.

\begin{tabular}{|l|l|}
\hline \multicolumn{2}{|c|}{ Description } \\
\hline Scope of Supply: & $\begin{array}{l}\text { Mass Flow Controller suitable for } \\
\text { controlling, measuring and } \\
\text { display of ammonia gas }\end{array}$ \\
\hline Medium & Anhydrous ammonia gas \\
\hline Ammonia flow range (LPM) & $0.4 \mathrm{LPM}$ to $2 \mathrm{LPM}$ \\
\hline Inlet Pressure range $\left(\mathrm{kg} / \mathrm{cm}^{2}\right)$ & 0.5 to 3 \\
\hline Medium temperature range & $10^{\circ} \mathrm{C}$ to $50^{\circ} \mathrm{C}$ \\
\hline Maximum allowable pressure drop & $0.05 \mathrm{~kg} / \mathrm{sq} . \mathrm{cm}$ \\
\hline
\end{tabular}

Flow selection Volumetric flow/Mass flow The mixed (ammonia and oxides of nitrogen) gas sent to SCR reactor to absorb the oxides of nitrogen in presence of catalyst. The anhydrous ammonia injection nozzle and mass flow controller is shown in figure.3(a),(b).
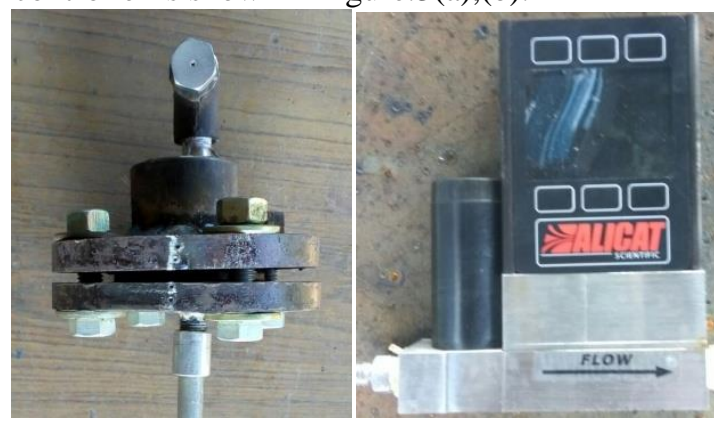

Figure 3(a) Ammonia Injection Nozzle \&. (b) Ammonia Mass flow Controller.

Ammonia is a gas at normal atmospheric temperature, therefore, it must be transported and stored under pressure. Anhydrous ammonia often requires special permission for transportation and storage. It is a colourless gas with a pungent odour that is noticeable at concentrations above 50 ppm. It is poisonous if inhaled in great quantities and is irritating to the eyes, nose, and throat in lesser amounts. The danger associated with ammonia is that it is explosive when mixed with air in certain proportions, approximately one volume of ammonia to two volumes of air, and is much more so when mixed with oxygen. The properties of anhydrous ammonia is shown in Table.

\begin{tabular}{|l|l|}
\hline Property & Anhydrous Ammonia \\
\hline $\begin{array}{l}\text { Liquid or gas at normal air } \\
\text { temperature }\end{array}$ & Liquid \\
\hline Ratio of ammonia to solution & $99.5 \%$ (by weight of $\mathrm{NH}_{3}$ ) \\
\hline Density of liquid at $60^{0} \mathrm{~F}$ & $5.1 \mathrm{lb} /$ gal \\
\hline Vapor pressure @ $80^{0} \mathrm{~F}$ & $153 \mathrm{psia}$ \\
\hline Flammability limits in air & $16-25 \% \mathrm{NH}_{3}$ (by volume) \\
\hline Short-term exposure limit & $35 \mathrm{ppm}$ \\
\hline Odor & Pungent odor @ 5 ppm or more \\
\hline & $\begin{array}{l}\text { Steel, rated for at least } 250 \text { psig } \\
\text { pressure ( no copper or } \\
\text { copper-based alloys, etc.,) }\end{array}$ \\
\hline Acceptable materials for storage
\end{tabular}

ADVANTAGES OF ANHYDROUS AMMONIA

- Lowest regent cost

- Lowest capital cost

- Lowest operating cost

- Simplistic Design

- Fewest product deliveries

- Easily available

\section{DIS-ADVANTAGES OF ANHYDROUS AMMONIA}

- It must be stored and handled under high pressure

- Highest permitting costs

- Largest number of regulatory issues

IMPORTANT SAFETY POINTS

- Always have an ample water supply close by;

- Always wear personal protective equipment;

- Never fill a tank over 85 percent of its capacity;

- Inspect hoses and valves regularly;

- Replace hoses at least every five years;

- Bleed off pressure in the hose before disconnecting it;

- Stay clear of hose and valve openings;

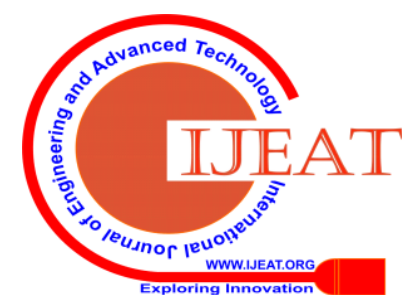


- Follow step-by-step procedures when using the equipment;

- Never try to repair the tank yourself - seek a qualified technician;

\section{STATIC MIXTURE}

Static mixture is an equipment which is used to mix thoroughly the oxides of Nitrogen $\left(\mathrm{NO}_{\mathrm{x}}\right.$ ) available in flue gas with anhydrous ammonia. The performance of the catalyst is totally depends upon the quality of mixing in the static mixture.

\section{SCR REACTOR HOUSING}

The honeycomb catalyst is enclosed in a fabricated stainless steel housing called SCR reactor. The size of the SCR reactor is $94 \mathrm{~mm}$ X $94 \mathrm{~mm}$ X $750 \mathrm{~mm}$ of 3 modules. As the same way $86 \mathrm{~mm}$ X $86 \mathrm{~mm}$ X $730 \mathrm{~mm}$ plate type is also mounted.

\section{SCR CATALYST}

Catalyst is the heart of De- $\mathrm{NO}_{\mathrm{x}}$ process. There are two types of catalysts are available; honeycomb \& plate type catalyst. The honeycomb and plate type catalyst with $8 \mathrm{~mm}$ pitch has been used for reduction of oxides of nitrogen $\left(\mathrm{NO}_{\mathrm{x}}\right)$ from flue gas. Anhydrous gaseous ammonia reacts with $\mathrm{NO}_{\mathrm{x}}$ in flue gas to form nitrogen $\left(\mathrm{N}_{2}\right)$ and water vapour $\left(\mathrm{H}_{2} \mathrm{O}\right)$ in presence of honeycomb catalyst. The primary base material of catalyst is titanium dioxide $\left(\mathrm{TiO}_{2}\right)$, with smaller amounts of other metal oxides including tungsten oxide $\left(\mathrm{WO}_{2}\right)$ for thermal support and vanadium pentoxide $\left(\mathrm{V}_{2} \mathrm{O}_{5}\right)$, which is the primary active material.

The size of honeycomb is offered with $94 \mathrm{~mm}$ X $94 \mathrm{~mm} \mathrm{X}$ $750 \mathrm{~mm}$ of 3 Modules with $8 \mathrm{~mm}$ pitch and $1 \mathrm{~mm}$ wall thickness. The total volume of the catalyst is $0.0198 \mathrm{~m}^{3}$ $(0.094 * 0.094 * 0.75 * 3)$. And plate catalyst $086 \mathrm{~mm}$ X $86 \mathrm{~mm}$ $\mathrm{X} 730 \mathrm{~mm}$ of 3 modules. The pictorial view of $8 \mathrm{~mm}$ pitch honeycomb and plate catalyst has been shown in figure. To provide a large gas contact area with a minimum pressure loss, the honeycomb catalyst is provided as 64 elements containing a large number of parallel channels .
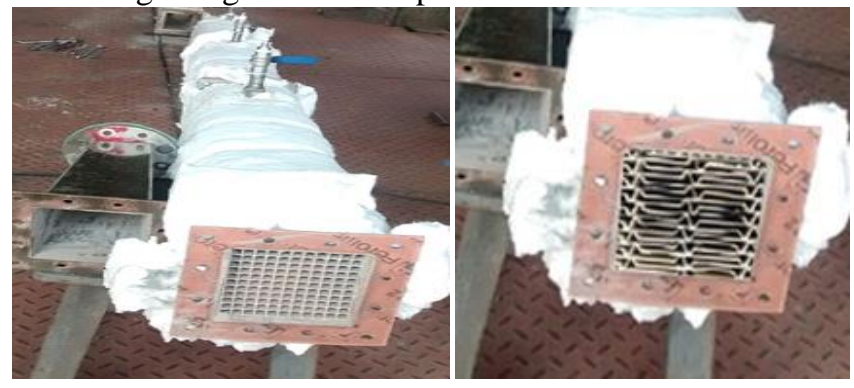

Figure 4.Pictorial View of $8 \mathrm{~mm}$ (a) Honeycomb and (b) plate Catalyst along with casing

\section{SCR PERFORMANCE PARAMETERS}

The rate of the reduction reaction determines the amount of $\mathrm{NO}_{\mathrm{x}}$ removed from the flue gas. The major design and operational factors that affect the $\mathrm{NO}_{\mathrm{x}}$ removal performance of SCR are:

- Reaction temperature range

- Residence time available in the optimum temperature range

- Degree of mixing of anhydrous ammonia and flue gas composition
- Molar ratio of anhydrous ammonia to inlet NOx

\section{VENTURI FLOW METER}

A venturi flow meter has been installed at the exit of SCR reactor, to measure the flue gas flow rate. The installed capacity of the venture flow meter is $150 \mathrm{Nm}^{3} / \mathrm{hr}$

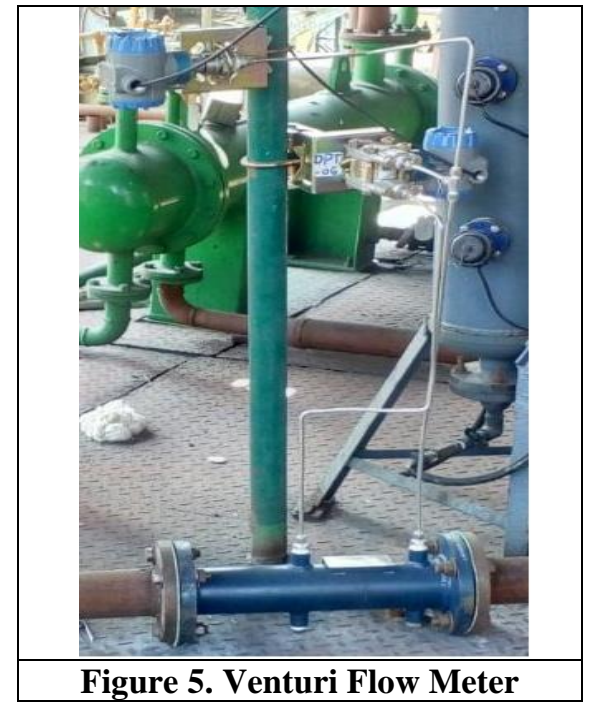

\section{EXPERIMENTAL PROCEDURE}

The existing 200mm advanced pressurized Fluidized Bed gasification (APFBG) pilot plant was operated in a combustion mode and generated flue gas for testing of $8 \mathrm{~mm}$ pitch honeycomb and plate catalyst performance. The Process and Instrumentation diagram (P\&ID) and pictorial view of SCR test facility for De- $\mathrm{NO}_{\mathrm{x}}$ process is shown in Figure 1.The performances of honeycomb and plate catalysts were tested with high dust (30-52 grams/ $\mathrm{Nm}^{3}$ ) concentration in flue gas.

For testing of honeycomb and plate catalysts with dust, flue gas generated from the gasifier and sent directly to dust measurement system where the dust concentration was measured with help of on-line dust monitoring system. Once the dust measured using on-line dust measurement system, the flue gas was sent to immersion heating coil to heat the flue gas to a required SCR inlet temperature (300 to 350 Deg.C) and is shown in figure 8(a). Then the inlet $\mathrm{NO}_{\mathrm{x}}$ concentration was measured using flue gas analyser and is shown in figure 2.

Subsequently the required quantity of Anhydrous Ammonia was admitted with help of ammonia mass flow controller in to flue gas pipe line through ammonia injection nozzle. The pictorial view of ammonia mass flow controller and ammonia flow nozzle is shown in figure 3 (a) \& 3 (b). The quantity of anhydrous ammonia is calculated based on the flue gas flow rate and $\mathrm{NO}_{\mathrm{x}}$ concentration in the flue gas. Once the anhydrous ammonia injected in to flue gas, the mixture of ammonia $\left(\mathrm{NH}_{3}\right)$ and Oxides of Nitrogen $\left(\mathrm{NO}_{\mathrm{x}}\right)$ gas was sent to static mixture for better mixing of ammonia and oxides of nitrogen in the flue gas. Then the mixture sent in to SCR reactor to reduce the oxides of nitrogen $\left(\mathrm{NO}_{\mathrm{x}}\right)$ in presence of honeycomb and plate catalyst for $\mathrm{NO}_{\mathrm{x}}$ reduction at required SCR inlet temperature. The temperature, pressure and differential pressures are measured across the SCR 
reactor using E-type thermocouples, pressure transmitters and differential transmitters respectively. Once the reaction completed in SCR reactor, the flue gas passes through gas venturi flow meter to measure the flue gas flow rate for calculating the space velocity. The outlet NOx concentration and ammonia slip also measured before vent off to the atmosphere using flue gas analyzer and ammonia gas analyzer respectively.

The $\mathrm{NO}_{\mathrm{x}}$ conversion rate was calculated based on the inlet and outlet $\mathrm{NO}_{\mathrm{x}}$ concentration of the SCR reactor.

The experiments were conducted to evaluate performance of $8 \mathrm{~mm}$ honeycomb and plate catalysts in 20 liters capacity SCR test facility. The flue gas was generated from APFBG pilot plant by operating in combustion mode. to generate the flue gas for testing of in-house developed catalyst.. Feed particle size has been maintained more or less same for all the experiments and which was +0.5 to $-4.0 \mathrm{~mm}$.

The fluidized bed gasifier generates the flue gas by operating in combustion mode. The flue gas composition consists of carbon di-oxide $\left(\mathrm{CO}_{2}\right)$, water $\left(\mathrm{H}_{2} \mathrm{O}\right)$, oxygen $\left(\mathrm{O}_{2}\right)$, nitrogen $\left(\mathrm{N}_{2}\right)$, nitrous oxide $(\mathrm{NO})$, nitrogen di-oxide $\left(\mathrm{NO}_{2}\right)$, sulphur di-oxide $\left(\mathrm{SO}_{2}\right)$, and Argon ( $\left.\mathrm{Ar}\right)$. The generated flue gas composition in volume percentage wise is shown in table

\begin{tabular}{|c|c|}
\hline Flue Gas Composition (Vol \%) \\
\hline Carbon di-oxide $\left(\mathrm{CO}_{2}\right)$ & 12 \\
\hline Water $\left(\mathrm{H}_{2} \mathrm{O}\right)$ & 8.5 \\
\hline Oxygen $\left(\mathrm{O}_{2}\right)$ & 6.24 \\
\hline Nitrogen $\left(\mathrm{N}_{2}\right)$ & 71.9755 \\
\hline Oxides of Nitrogen (NOx) & 0.04 \\
\hline Oxides of Sulphur (SOx) & 0.03 \\
\hline Argon (Ar) & 1.2 \\
\hline Average Molecular Weight & 29.46952 \\
\hline
\end{tabular}

The generated flue gas was sent to honeycomb and plate type catalysts to evaluate the $\mathrm{NO}_{\mathrm{x}}$ removal efficiency and ammonia slip by varying the space velocities and flue gas temperatures with and without dust concentration in flue gas respectively. The following parameters are measured continuously while testing of Honeycomb and plate type catalysts respectively

1. Inlet \& outlet $\mathrm{NO}_{\mathrm{x}}$ concentration at SCR reactor

2. Anhydrous ammonia flow rate

3. Flue gas flow rate

4. Ammonia slip.

5. Reaction temperature range;

6. Differential pressure across the SCR reactor

7. Pressure at inlet and outlet of SCR reactor

\section{RESULTS AND DISCUSSION}

The $\mathrm{NO}_{\mathrm{x}}$ reduction reaction takes place in presence of SCR catalyst. The SCR reactor contains a honeycomb and plate type catalysts of $94 \mathrm{~mm}$ X $94 \mathrm{~mm}$ X $750 \mathrm{~mm}$ size of 3 modules with $8 \mathrm{~mm}$ pitch of 64 numbers and plate type catalyst is $86 \mathrm{~mm} \mathrm{X} 86 \mathrm{~mm}$ X $730 \mathrm{~mm}$ long to get about 20 liter catalyst volume. When the mixture (Flue gas and ammonia) is admitted in to SCR reactor, the available $\mathrm{NO}_{\mathrm{x}}$ in the flue gas is reacted with ammonia in presence of catalyst and converted in to nitrogen $\left(\mathrm{N}_{2}\right)$ and water $\left(\mathrm{H}_{2} \mathrm{O}\right)$. The catalytic reduction process consists of primary and secondary reactions and those are shown below:

\section{EXPERIMENTAL RESULTS}

\section{Primary reactions}

$$
\begin{aligned}
& 4 \mathrm{NO}+4 \mathrm{NH}_{3}+\mathrm{O}_{2} \rightarrow 4 \mathrm{~N}_{2}+6 \mathrm{H}_{2} \mathrm{O} \\
& 2 \mathrm{NO}_{2}+4 \mathrm{NH}_{3}+\mathrm{O}_{2} \rightarrow 3 \mathrm{~N}_{2}+6 \mathrm{H}_{2} \mathrm{O} \\
& \mathrm{NO}+\mathrm{NO}_{2}+2 \mathrm{NH}_{3} \rightarrow 2 \mathrm{~N}_{2}+3 \mathrm{H}_{2} \mathrm{O} \\
& \text { Secondary reactions } \\
& 2 \mathrm{SO}_{2}+\mathrm{O}_{2} \rightarrow 2 \mathrm{SO}_{3} \\
& 2 \mathrm{NH}_{3}+\mathrm{SO}_{3}+\mathrm{H}_{2} \mathrm{O} \rightarrow(\mathrm{NH} 4)_{2} \mathrm{SO}_{4} \\
& \mathrm{NH}_{3}+\mathrm{SO}_{3}+\mathrm{H}_{2} \mathrm{O} \rightarrow \mathrm{NH}_{4} \mathrm{HSO}_{4}
\end{aligned}
$$

\section{NOX REMOVAL EFFICIENCY}

The $\mathrm{NO}_{\mathrm{x}}$ removal efficiency, represented as $\eta_{\mathrm{NOx}}$, is determined from the inlet and outlet $\mathrm{NO}_{\mathrm{x}}$ concentration of $\mathrm{SCR}$. The equation for the $\mathrm{NO}_{\mathrm{x}}$ removal efficiency is given by:

$$
\text { NOx Removal Efficiency } \eta_{\mathrm{NOx}}: \frac{\text { NOxin - NOxout }}{\text { NOxin }}
$$

Where:

$\eta_{\mathrm{NOx}}=\mathrm{NO}_{\mathrm{x}}$ removal efficiency, fraction

$\mathrm{NO}_{\text {xin }}=$ Inlet $\mathrm{NO}_{\mathrm{x}}$ rate to the SCR,

$\mathrm{NO}_{\text {xout }}=$ outlet $\mathrm{NO}_{\mathrm{x}}$ rate from the SCR.

\section{SPACE VELOCITY (1/hr)}

The space velocity is defined as the ratio of volumetric flow rate of flue gas and the catalyst volume. It is commonly regarded as the reciprocal of the residence time. The units are per hour

\section{SCR HONEYCOMB CATALYST WITH DUST CONCENTRATION}

\section{Flue Gas Flow Rate Vs De-Nox Efficiency}

Figure 6. Shows the De-NOx efficiency as a function of Flue gas flow rate. To generate the Flue gas flow rate Vs De- $\mathrm{NO}_{x}$ efficiency performance curve, this experiment was conducted in a 20 litre capacity SCR test facility by varying the flow rate of $31.80,41.75 \& 51.70 \mathrm{Nm}^{3} / \mathrm{hr}$ which is an equivalent to the space velocity of $1000,1500 \& 2000$

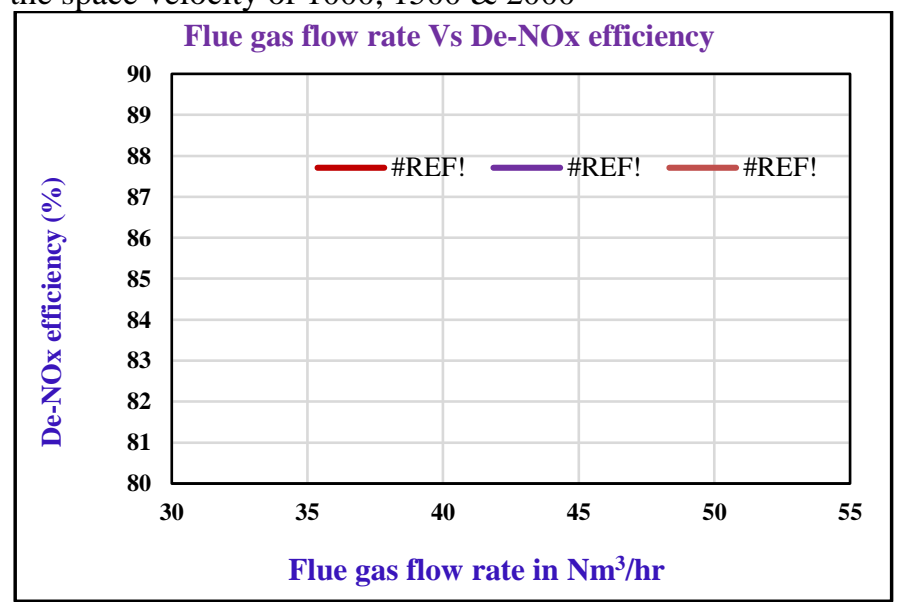

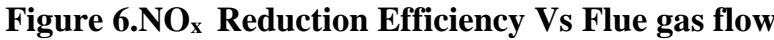
rate at $300,325 \& 350$ Deg.C

$\mathrm{Nm}^{3} / \mathrm{hr}$. Also the SCR inlet temperature varied in the range of 300 to 350 Deg.C and the molar ratio of ammonia $\left(\mathrm{NH}_{3}\right)$ to oxides of nitrogen $\left(\mathrm{NO}_{\mathrm{x}}\right)$ varied in the range of 0.9 to 1.0 but reported only $0.9\left(\mathrm{NH}_{3}: \mathrm{NO}_{\mathrm{x}}=0.9\right)$ due to avoid more ammonia slip. 
The results show that the De- $\mathrm{NO}_{\mathrm{x}}$ efficiency increases with decrease in flue gas flow rate which could be attributed due to less residence time. The residence time is the major parameter which greatly affects the De- $\mathrm{NO}_{\mathrm{x}}$ efficiency in SCR catalyst.When the flue gas flow rate increases, the residence time decreases which means the flue gas spent very less time in SCR reactor which leads to reduction in reaction rate between $\mathrm{NOx}$ and $\mathrm{NH}_{3}$. When the flue gas flow rate increases from flue gas flow rate is 31.80 to $51.70 \mathrm{Nm}^{3} / \mathrm{hr}$, the De- $\mathrm{NO}_{\mathrm{x}}$ efficiency decreased from 86.75 to $81.89 \%$ at different temperatures (300 -350 Deg.C).

\section{FLUE GAS FLOW RATE VS PRESSURE DROP} ACROSS SCR REACTOR

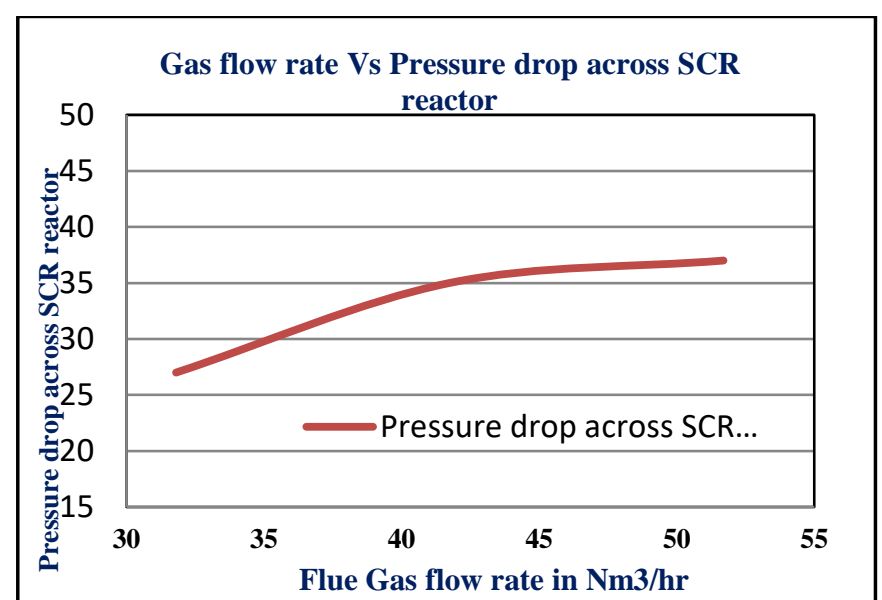

Figure 7.Flue gas flow rate Vs pressure drop across SCR reactor

Figure .7. Shows the pressure drop across SCR reactor as a function of flue gas flow rate to generate the flue gas flow rate Vs pressure drop across SCR reactor performance graph, this experiment was conducted in a 20 liter capacity SCR test facility by varying the flue gas flow rate at $31.80,41.75 \&$ $51.70 \mathrm{Nm}^{3} / \mathrm{hr}$ which is an equivalent to the space velocity of $1000,1500 \& 2000 / \mathrm{hr}$ respectively.

The results show that the pressure drop across SCR catalyst increases with increase in flue gas flow rate. The pressure drop across SCR catalyst is a function of the length of the catalyst, catalyst configuration and deposition of fly ash over the catalyst. The measured dust concentration at a flow rate of $51.70,41.75 \& 31.80 \mathrm{Nm}^{3} / \mathrm{hr}$ was $30-32,45-47$ and 50-52 grams $/ \mathrm{nm}^{3}$ respectively.

It also been observed that the pressure drop across SCR reactor is varying from $20 \mathrm{mmWc}$ to $38 \mathrm{mmWc}$ over a $2250 \mathrm{~mm}$ catalyst length.

\section{AMMONIA SLIP VS FLUE GAS FLOW RATE}

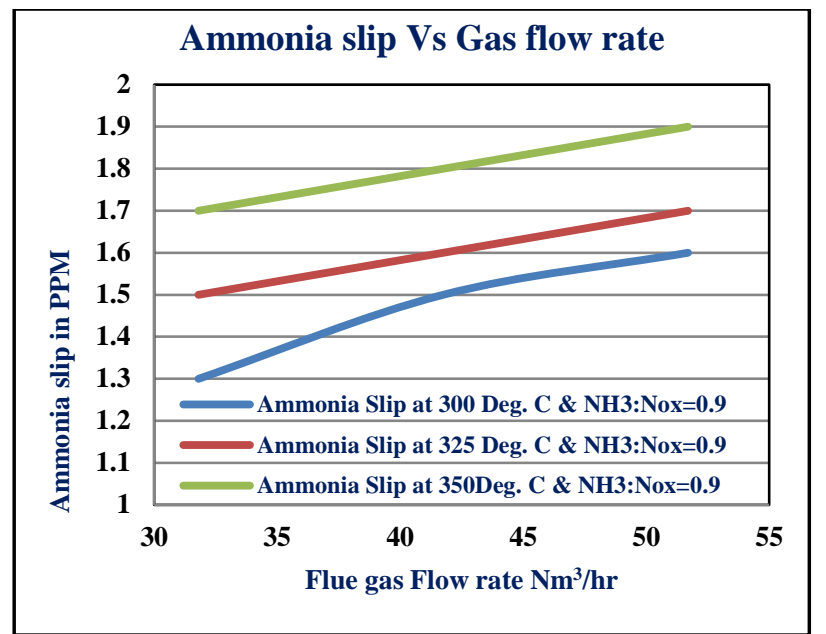

Figure 8. Ammonia slip Vs gas flow rate

Figure .8. Shows the ammonia slip as a function Flue gas flow rate. To generate the Ammonia slip Vs Flue gas flow rate performance curve, this experiment was conducted in a 20 litre capacity SCR test facility by varying the flue gas flow rate of $31.80,41.75 \& 51.70 \mathrm{Nm}^{3} / \mathrm{hr}$. Also varied the SCR inlet temperature in the range of 300-350 deg. $\mathrm{C}$ and the molar ratio of ammonia $\left(\mathrm{NH}_{3}\right)$ to oxides of nitrogen $\left(\mathrm{NO}_{\mathrm{x}}\right)$ in the range of 0.9 to 1.0 but reported only $0.9\left(\mathrm{NH}_{3}: \mathrm{NO}_{\mathrm{x}}=0.9\right)$ due to avoid more ammonia slip.

The results show that the Ammonia slip increases as the flue gas flow rate increases which could be attributed due lower residence time. When the flue gas flow rate increases from 1000 to $2000 \mathrm{Nm}^{3} / \mathrm{hr}$, the ammonia slip increases from 1.3 to $1.9 \mathrm{ppm}$ at the molar ratio of ammonia $\left(\mathrm{NH}_{3}\right)$ to oxides of nitrogen $\left(\mathrm{NO}_{\mathrm{x}}\right)$ in the range of 0.9 . When the flue gas flow increases, the residence time decreases when the residence time decreases the reactivity also decreases. When the reactivity decreases the ammonia slip increases. Ammonia slip also increases as the catalyst activity decreases. The allowable ammonia slip approximately less than 2 ppm [3].

SCR PLATE TYPE CATALYST PERFORMANCE CURVES

FLUE GAS FLOW RATE VS DE-NO ${ }_{x}$ EFFICIENCY

Figure 9: Shows the De-NOX efficiency as a function of space velocity. To generate the space velocity $\mathrm{Vs}$ De- $\mathrm{No}_{\mathrm{X}}$ efficiency performance curve, this experiment was conducted in a 20 litre capacity SCR test facility by varying the flow rate of $24.30,32.40 \& 40.50 \mathrm{Nm}^{3} / \mathrm{hr}$ at a space velocity of 1000 to $2100 / \mathrm{hr}$. Also the SCR inlet temperature varied in the range of 300 to 350 Deg.C and the molar ratio of ammonia $\left(\mathrm{NH}_{3}\right)$ to oxides of nitrogen $\left(\mathrm{NO}_{\mathrm{X}}\right)$ varied in the range of 0.9 to 1.0 but reported only $0.9\left(\mathrm{NH}_{3}: \mathrm{NO}_{\mathrm{X}}=0.9\right)$ due to avoid more ammonia slip. The results show that the De- $\mathrm{NO}_{\mathrm{x}}$ efficiency increases with decrease in flue gas flow rate which could be attributed due to less residence time. The residence time is the major parameter which greatly affects the De-NOx efficiency in SCR catalyst.When the flue gas flow rate increases, the residence time decreases which means the flue gas spent very less time in SCR reactor which leads to reduction in reaction rate between $\mathrm{NO}_{\mathrm{x}}$ and $\mathrm{NH}_{3}$. 


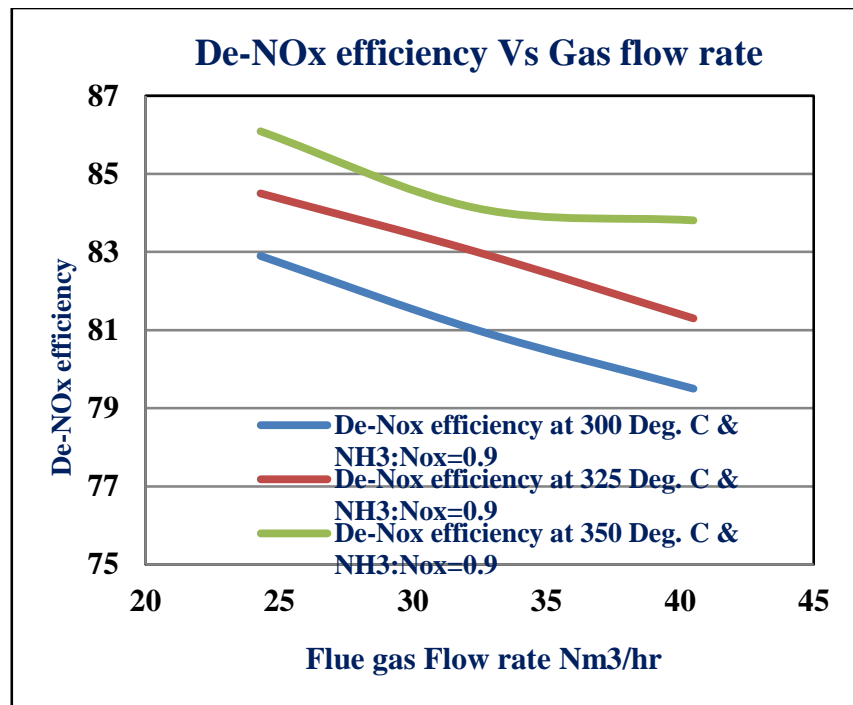

Figure 9. Flue gas Flow rate Vs De-NOx efficiency

When the flue gas flow rate increases from flue gas flow rate is 31.80 to $51.70 \mathrm{Nm}^{3} / \mathrm{hr}$, the De- $\mathrm{NO}_{\mathrm{x}}$ efficiency decreased from 86.09 to $79.45 \%$ and the $\mathrm{NO}_{\mathrm{x}}$ reduction efficiency increases with increase in temperature up to 350 Deg C. $\mathrm{NO}_{\mathrm{x}}$ reduction efficiency increased from 82.91 to $85.88 \%$ at different temperatures (300 -350 Deg.C).

\section{FLUE GAS FLOW RATE VS PRESSURE DROP} ACROSS SCR REACTOR.

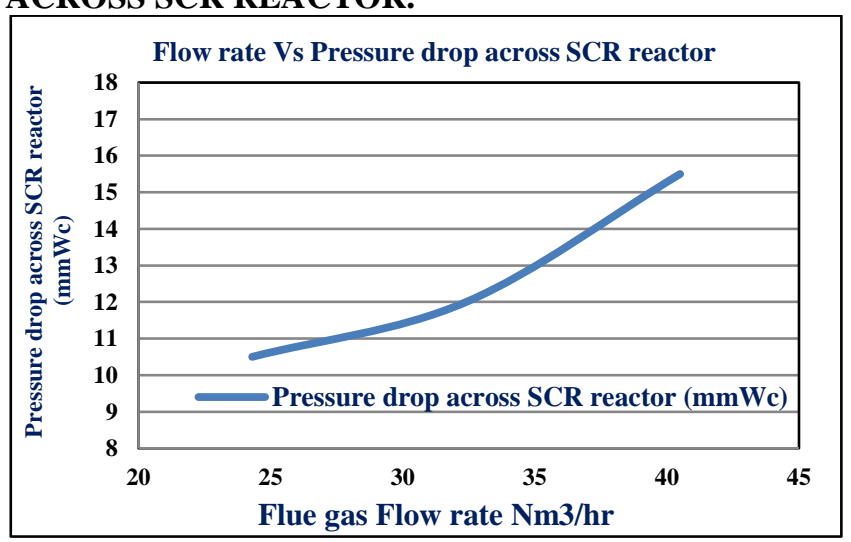

Figure 10. Flue gas flow rate Vs pressure drop across SCR reactor

Figure 10. Shows the Pressure drop across SCR reactor as a function of flue gas flow rate. To generate the flue gas flow rate Vs pressure drop across SCR reactor performance graph, this experiment was conducted in a 20 litre capacity SCR test facility by varying the flue gas flow rate at $24.30,32.40$ \& $40.50 \mathrm{Nm}^{3} / \mathrm{hr}$ and space velocity of $1000,1500 \& 2000 / \mathrm{hr}$ respectively. The results show that the pressure drop across SCR catalyst increases with increase in flue gas flow rate. The pressure drop across SCR catalyst is a function of the length of the catalyst, catalyst configuration and deposition of fly ash over the catalyst. The measured dust concentration at a flow rate of $51.70,41.75 \& 31.80 \mathrm{Nm}^{3} / \mathrm{hr}$ was $30-32$, 45-47 and $50-52$ grams $/ \mathrm{nm}^{3}$ respectively.

It also been observed that the pressure drop across SCR reactor is varying from $10.46 \mathrm{mmWc}$ to $15.50 \mathrm{mmWc}$ over a $2190 \mathrm{~mm}$ catalyst length.
AMMONIA SLIP VS FLUE GAS FLOW RATE.

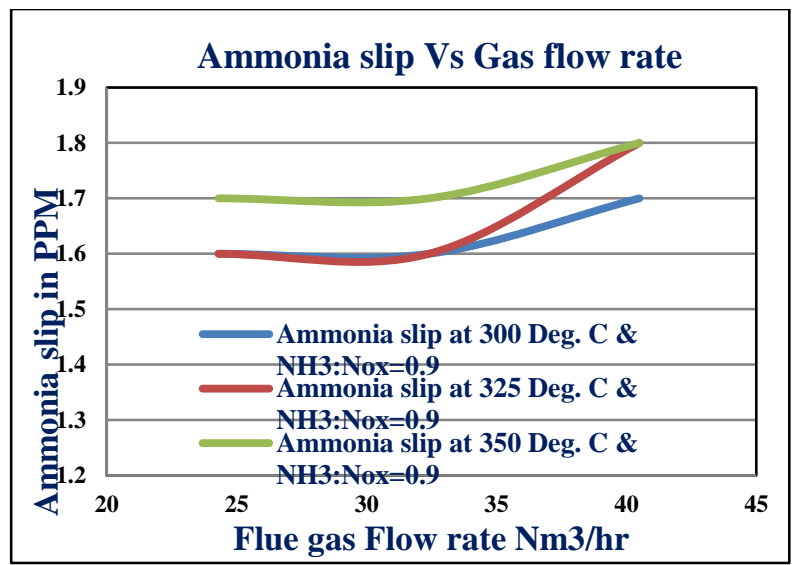

Figure 11. Ammonia slip Vs Flue gas flow rate

Figure11. Shows the ammonia slip as a function of Flue gas flow rate. To generate the ammonia slip vs flue gas flow rate performance curve, this experiment was conducted in a 20 litre capacity SCR test facility by varying the flue gas flow rate of $24.30,32.40 \& 40.50 \mathrm{Nm}^{3} / \mathrm{hr}$. Also varied the SCR inlet temperature in the range of 300-350 deg. $\mathrm{C}$ and the molar ratio of ammonia $\left(\mathrm{NH}_{3}\right)$ to oxides of nitrogen $\left(\mathrm{NO}_{\mathrm{x}}\right)$ in the range of 0.9 to 1.0 but reported only $0.9\left(\mathrm{NH}_{3}: \mathrm{NO}_{\mathrm{x}}=0.9\right)$ due to avoid more ammonia slip. The results show that the Ammonia slip increases as the flue gas flow rate increases which could be attributed due lower residence time. When the space velocity increases from 1000 to $2000 \mathrm{Nm}^{3} / \mathrm{hr}$, the ammonia slip increases from 1.6 to $1.8 \mathrm{ppm}$ at the molar ratio of ammonia $\left(\mathrm{NH}_{3}\right)$ to oxides of nitrogen (NOx) in the range of 0.9. When the flue gas flow increases, the residence time decreases when the residence time decreases the reactivity also decreases. When the reactivity decreases the ammonia slip increases. Ammonia slip also increases as the catalyst activity decreases. The allowable ammonia slip approximately less than $2 \mathrm{ppm}$ [3].

\section{COMPARISSION}

Efficiency's for honeycomb and Plate type catalyst's at different space velocity's and different temperatur's.

\begin{tabular}{|c|c|c|c|}
\hline \multirow{2}{*}{$\begin{array}{c}\text { Flow rate vs } \\
\text { Avg Temp }\end{array}$} & \multicolumn{3}{|c|}{ HONEYCOMB } \\
\cline { 2 - 4 } & 300 & 325 & 350 \\
\hline $31.80 \mathrm{Nm}^{3} / \mathrm{hr}$ & $84.50 \%$ & $85.84 \%$ & $86.75 \%$ \\
\hline \multirow{4}{*}{$41.75 \mathrm{Nm}^{3} / \mathrm{hr}$} & $83.15 \%$ & $84.25 \%$ & $85.72 \%$ \\
\hline \multirow{3}{*}{$51.70 \mathrm{Nm}^{3} / \mathrm{hr}$} & $81.92 \%$ & $83.24 \%$ & $84.07 \%$ \\
\hline & \multicolumn{3}{|c|}{ PLATE TYPE } \\
\hline \multirow{2}{*}{$\begin{array}{c}\text { Flow rate vs } \\
\text { Avg Temp }\end{array}$} & 300 & 325 & 350 \\
\hline \multirow{2}{*}{$24.30 \mathrm{Nm}^{3} / \mathrm{hr}$} & $82.90 \%$ & $84.51 \%$ & $85.62 \%$ \\
\hline \multirow{2}{*}{$32.40 \mathrm{Nm}^{3} / \mathrm{hr}$} & $81.01 \%$ & $83.01 \%$ & $84.14 \%$ \\
\hline $40.50 \mathrm{Nm}^{3} / \mathrm{hr}$ & $79.50 \%$ & $82.01 \%$ & $84.01 \%$ \\
\hline
\end{tabular}

1. Ammonia slip measured was in the range of 1.4 to 3.8 ppm for honeycomb catalyst and with plate type was 1.6- $4.7 \mathrm{ppm}$ at $0.9 \& 1.0$ for ammonia to oxides of nitrogen.

2. The total differential Pressure (DP) across honeycomb SCR catalyst was 25-38 mmWc over a 2250mm length

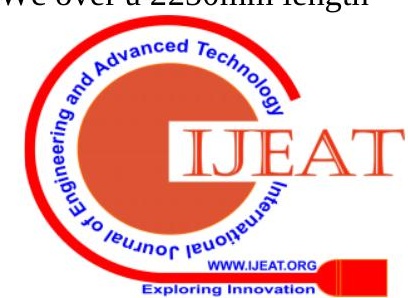


and for plate type SCR catalyst was 9-18 mmWc over a 2100mm length.

3. Surface area is high in honeycomb and quite less in plate type.

4. Back pressure is high in honeycomb and less in plate type.

5. Ash struck in the chamber is observed in honeycomb and while coming to plate it is too less.

6. We have achieved max $\mathrm{NO}_{\mathrm{x}}$ efficiency at gas flow rate of $31.80 \mathrm{Nm}^{3} / \mathrm{hr}, 41.75 \mathrm{Nm}^{3} / \mathrm{hr}, 51.70 \mathrm{Nm}^{3} / \mathrm{hr}$ for honeycomb and $24.30 \mathrm{Nm}^{3} / \mathrm{hr}, 32.40 \mathrm{Nm}^{3} / \mathrm{hr}, 40.50$ $\mathrm{Nm}^{3} / \mathrm{hr}$ for plate type.

\section{SUMMARY}

The existing 200mm advanced pressurized fluidized bed gasification (APFBG) pilot plant was operated in a combustion mode and generated flue gas for testing of $8 \mathrm{~mm}$ Honeycomb and plate type catalyst to evaluate the catalyst efficiency. To evaluate the honeycomb and plate type catalyst, three modules of each in-house developed honeycomb and plate type SCR catalysts were tested in a 20 liter capacity SCR pilot plant. The size of the each honeycomb is $94 \mathrm{~mm} \times 94 \mathrm{~mm}$ X $750 \mathrm{~mm}$ long and plate type catalyst is $86 \mathrm{~mm}$ X $86 \mathrm{~mm}$ X $730 \mathrm{~mm}$ long to get about 20 liter catalyst volume. The process and instrumentation diagram (P\&ID) of 20 liters SCR test Facility for De- $\mathrm{NO}_{\mathrm{x}}$ system is shown in Figure 1. The performance of honeycomb and plate type catalysts were evaluated by varying the dust concentration from $30-52 \mathrm{~g} / \mathrm{Nm}^{3}$ in flue gas. Also varied the flue gas flow rate of $31.80,41.75 \& 51.70 \mathrm{Nm}^{3} / \mathrm{hr}$ which is an equivalent to the space velocity of $1000,1500 \& 2000 \mathrm{Nm}^{3} / \mathrm{hr}$ and 1600 , $2102 \& 2600 / \mathrm{hr}$ respectively. Also the SCR inlet temperature is varied in the range of 300 to 350 Deg.C and the molar ratio of ammonia $\left(\mathrm{NH}_{3}\right)$ to oxides of nitrogen $\left(\mathrm{NO}_{\mathrm{x}}\right)$ is varied in the range of 0.9 to 1.0 for all experiments. Also measured the inlet $\mathrm{NO}_{\mathrm{x}}$, outlet $\mathrm{NO}_{\mathrm{x}}$, Inlet dust concentration, pressures, differential pressures across static mixture \& SCR reactor and ammonia slip at out let of the SCR reactor. The following performance curves were generated to evaluate the honeycomb and plate type catalysts.

\section{CONCLUSIONS}

Experiments were carried out to generate the performance curves on in-house developed 8mm Pitch Honeycomb and Plate type catalysts in a 20 litre volume capacity SCR test facility. The flue gas was generated from 200mm Advanced Pressurized Fluidized Bed Gasification (APFBG) pilot plant by operating in combustion mode. The $\mathrm{NO}_{\mathrm{x}}$ removal efficiency and ammonia slip was investigated with dust concentration of $38-50$ grams/ $\mathrm{Nm}^{3}$ in flue gas by varying the space velocities (2500-1500 per hr.) and flue gas temperatures $\left(300-350^{\circ} \mathrm{C}\right)$ using anhydrous ammonia as reducing agent.

- In-house developed 8mm pitch honeycomb and plate type SCR catalysts were tested in a 20-liter capacity SCR test facility with dust concentration in the range of 38-50 grams $/ \mathrm{nm}^{3}$ by varying the space velocities (2500-1500 per hr.) and flue gas temperatures in the range of $300-350^{\circ} \mathrm{C}$ using anhydrous ammonia as reducing agent.
- NOx reduction efficiency achieved with honeycomb was $81.89-86.75 \%$ and with plate type was $79.50-85.62 \%$ at 2500-1500 per hr. space velocities and the ratio of ammonia $\left(\mathrm{NH}_{3}\right)$ to oxides of nitrogen $\left(\mathrm{NO}_{\mathrm{x}}\right)$ was maintained at 0.9 .

- $\mathrm{NO}_{\mathrm{x}}$ reduction efficiency achieved with honeycomb was $82.72-88.23 \%$ and with plate type was $80.43-87.41 \%$ at 2500-1500 per hr. space velocities and the ratio of ammonia $\left(\mathrm{NH}_{3}\right)$ to oxides of nitrogen $\left(\mathrm{NO}_{\mathrm{x}}\right)$ was maintained at 1.0 .

- $\quad$ Ammonia slip measured was in the range of 1.4 to 3.8 ppm for honeycomb catalyst and with plate type was 1.6$4.7 \mathrm{ppm}$ at $0.9 \& 1.0$ for ammonia to oxides of nitrogen.

- The total Differential Pressure (DP) across Honeycomb SCR catalyst was $25-38 \mathrm{mmWc}$ over a $2250 \mathrm{~mm}$ length and for plate type SCR catalyst was 9-18 mmWc over a $2100 \mathrm{~mm}$ length.

Finally, it can be concluded that, the $8 \mathrm{~mm}$ pitch honeycomb and plate type SCR catalysts are very much suitable for reduction of Oxides of Nitrogen (NOx) in the range of $80-90 \%$ in flue gas with dust concentration of 30-52 grams $/ \mathrm{Nm}^{3}$ which are meeting the power plant requirements

\section{REFERENCES}

1. Institute of Clean Air Companies (ICAC). Selective Catalytic Reduction (SCR) Control of NOx Emissions, Prepared by the ICAC SCR Committee, November 1997.

2. Selective Catalytic Reduction of NOx controls section 4, EPA/452/B-02-001.

3. International Energy Outlook 2016, report no. DOE/EIA-0484(2016) I May 2016.

4. Latest Selective Catalytic Reduction (SCR) Technologies for DeNOx Plants, Christoph M. Heinisch, Experts - September 2013.

5. Christoph M. Heinisch, Air Economics Group, Chapter 2 of Selective Catalytic Reduction, June 2015.

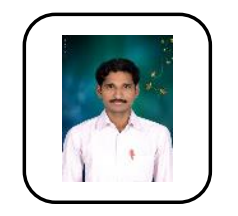

\section{AUTHORS PROFILE}

D. Eswaraiah, Currently his working as a asst.Prof in Gokaraju Rangaraju Institute of engineering and technology, HYDERABAD and is done his M.Tech (Thermal Engineering) in JNTU-Hyderabad, B.Tech. (Mechanical Engineering), Acharya Nagarjuna University, Guntur. And He published three international journals, His area of interests are heat transfer, refrigeration and air conditioning, thermodynamics, CFD,EDTS.

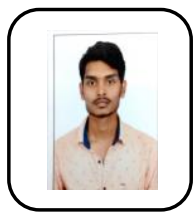

Karthik Gudipudi, M. Tech (Thermal Engineering) from Gokaraju Rangaraju Institute of engineering and technology -Hyderabad, B.Tech, (Mechanical Engineering) from Khammam institute of technology and sciences (KITS), khammam. His areas of interest are hea transfer applications, thermodynamics and strength of materials.

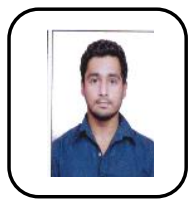

U.Harish kumar, M. Tech (Thermal Engineering) from Gokaraju Rangaraju Institute of engineering and technology -Hyderabad,B.E(Mechanical Engineering) from Sri handrasekharendra Saraswathi Viswa Maha Vidhyalaya (SCSVMV) university Kancheepuram, Tamil Nadu (631561).His areas of interest are heat transfer,strength of materials. 